\title{
Pengaruh Biochar dan Pupuk Organik Cair dari Air Cucian Beras Terhadap Pertumbuhan dan Produksi Selada
}

\author{
The Effect of Biochar and Liquid Organic Fertilizer from Rice Wash Liquid Waste on the Growth \\ and Yield of Lettuce
}

\section{Deno Okalia*, Tri Nopsagiarti, Gusti Marlina}

\author{
Program studi Agroteknologi, Fakultas Pertanian, Universitas Islam Kuantan Singingi, Jl. Gatot Subroto Km 7, \\ Kabupaten Kuantan Singingi. Riau 29563, Indonesia \\ *Email Penulis Korespondensi: okalia88@gmail.com
}

\begin{abstract}
Growing vegetable crops such as lettuce, on Ultisol soil has several obstacles, such as insufficient organic matter and nutrients in the soil. The provision of biochar and POC leri or organic fertilizer from rice washing liquid is expected to be a longterm and sustainable solution. This study was intended to test the addition of biochar to the growing media and the application of leri on lettuce cultivation. This study used a factorial Randomized Block Design (RAK) method. The first factor was the application of biochar to the planting medium (M), which consisted of M1: Ultisol without biochar and M2: Ultisol $+30 \mathrm{~g}$ biochar. The second factor was the administration of liquid organic fertilizer (LOF) leri $(P)$, with 5 treatments consisting of P0: without giving LOF leri, P1: giving LOF leri without fermentation once a week, P2: giving LOF leri without fermentation twice a week, P3: giving fermented LOF leri once a week, P4: giving fermented LOF leri twice a week. The results of this study were tested statistically by analysis of variance, with the F test; if there was a significant difference, it was continued with the BNJ test (Honest Significant Difference) at a 0.05 level. The results showed that the best treatment of LOF leri in increasing lettuce growth and yield was $25 \%$ fermented LOF leri given 2 times a week, at $250 \mathrm{~mL}$ per lettuce plant. As a single treatment the best growing media was M2 (Ultisol soil $+30 \mathrm{~g}$ of biochar) with a plant height of $25.80 \mathrm{~cm}$ and the leaf number of 12.83; whereas the best LOF leri treatment was P4 (fermented LOF leri given twice a week), with a plant height of $30.27 \mathrm{~cm}$ and leaf number of 14.42. Based on whole plant fresh weight, the best treatment was the M2P4 (Ultisol + biochar growing medium and fermented LOF leri given week), which was $185.99 \mathrm{~g}$ per plant.
\end{abstract}

Keywords: Household waste, lettuce, POC leri, rice washing liquid

\section{ABSTRAK}

Melakukan budidaya tanaman sayuran, seperti selada, pada tanah Ultisol memiliki beberapa kendala, seperti kurangnya bahan organik dan unsur hara pada tanah tersebut. Pemberian biochar dan POC leri atau pupuk organik dari cairan cucian beras diharapkan dapat menjadi solusi yang bersifat jangka panjang dan berkelanjutan. Penelitian ini dimaksudkan untuk menguji penambahan biochar pada media tanam dan pemberian leri pada budidaya selada. Penelitian ini menggunakan metode Rancangan Acak Kelompok (RAK) faktorial. Faktor pertama adalah pemberian biochar pada media tanam (M), yang terdiri dari M1: Ultisol tanpa biochar dan M2: Ultisol + $30 \mathrm{~g}$ biochar. Faktor kedua adalah pemberian pupuk organic cair (POC) leri (P), dengan sebanyak 5 perlakuan yang terdiri dari adalah P0: tanpa pemberian POC leri, P1: pemberian POC leri tanpa fermentasi 1 kali seminggu, P2: pemberian POC leri tanpa fermentasi 2 kali seminggu, P3: pemberian POC leri fermentasi 1 kali seminggu, P4: pemberian POC leri fermentasi 2 kali seminggu. Hasil penelitian ini diuji secara statistik dengan analisis ragam, dengan uji F; bila terdapat perbedaan nyata dilanjutkan dengan uji BNJ (Beda Nyata Jujur) pada taraf 0,05. Hasil penelitian menunjukkan perlakuan POC leri yang terbaik dalam meningkatkan pertumbuhan dan produksi selada adalah 25\% POC leri fermentasi yang diberikan 2 kali seminggu, sebanyak $250 \mathrm{~mL}$ per tanaman selada. Secara tunggal perlakuan media tanam terbaik adalah M2 (tanah Ultisol+ $30 \mathrm{~g}$ biochar) dengan tinggi tanaman 25,80 cm dan jumlah daun 12, 83 helai; sedangkan perlakuan POC leri terbaik adalah P4 (POC leri fermentasi yang diberikan 2 kali seminggu), dengan tinggi tanaman 30,27 cm dan jumlah daun 14,42 helai. Berdasarkan berat basah tanaman, yang terbaik adalah pada perlakuan M2P4 (media tanam Ultisol + biochar dan POC leri fermentasi yang diberikan 2 kali seminggu), yaitu 185,99 g per tanaman.

Kata kunci: cairan cucian beras, limbah rumah tangga, POC leri, selada

\section{PENDAHULUAN}

Kondisi Indonesia yang sejak Februari 2020 mengalami wabah pandemi Covid19 telah sangat membatasi masyarakat dalam melakukan aktivitas sehari-hari. Dalam menghadapi wabah ini sangat diperlukan imunitas yang baik dengan cara mengkonsumsi makanan yang bergizi, seperti sayuran selada. Makanan yang bergizi terutama mengandung protein, lemak, karbohidrat, vitamin dan mineral yang dibutuhkan tubuh. Setiap $100 \mathrm{~g}$ berat basah selada mengandung 1,2 $\mathrm{g}$ protein, 0,2 g lemak, 22,0 mg Ca, 25,0 mg Fe, $162 \mathrm{mg}$ vitamin A, 0,04 mg vitamin B, 8,0 mg vitamin C (Haryanto 
et al., 2003). Selada merupakan salah satu sayuran yang dapat dikonsumsi dalam bentuk segar sehingga sangat digemari masyarakat.

Pengembangan tanaman hortikultura, seperti sayuran di Kabupaten Kuantan Singingi dihadapkan pada masalah tanah yang umumnya kurang subur, sehingga kebutuhan sayuran sering dipenuhi dengan mendatangkan dari propinsi tetangga, seperti Sumatera Barat. Berdasarkan laporan Dinas Tanaman Pangan Tahun (2013), Kuantan Singingi didominasi oleh tanah Podsolik merah kuning atau dalam klasifikasi taxonomi dikenal dengan nama Ultisol. Menurut Hakim (2006) ultisol merupakan tanah yang memiliki pH dan kandungan bahan organik rendah, keracunan Al, defisisensi P, dan miskin unsur hara, sehingga tanah tersebut harus dipupuk. Kendala sifat kimia tanah yang kurang subur tersebut sulit diatasi oleh petani dengan kemampuan yang terbatas. Dengan demikian, perlu dicari alternatif pupuk yang murah dan mudah didapat untuk mengatasi masalah tersebut. Salah satu bahan yang mudah didapat dan belum termanfaatkan dengan baik adalah biochar kayu dan limbah air cucian beras atau leri.

Biochar merupakan produk sampingan dari hasil pembakaran limbah pertanian dan perkebunan, seperti potongan ranting pohon, tandan kelapa sawit, tongkol jagung, batang singkong, sekam padi dan hasil produk pertanian. Biochar dibuat dengan memaparkan biomassa menggunakan suhu tinggi tanpa adanya oksigen, sehingga dapat dihasilkan gas sintetik dan bio-oil serta arang hayati yang dikenal dengan biochar. Biochar memiliki kandungan Corganik $>35 \%$, dan oleh karena itu biochar dapat dikembalikan ke tanah sebagai bahan pembenah tanah (Harryadi, 2016). Selain membutuhkan pembenah tanah dalam bentuk karbon pada tanah, perlu juga dilakukan penambahan unsur hara yang mudah diserap dalam bentuk pupuk organik cair. Pupuk organik cair dari air cucian beras atau leri mengandung banyak nutrisi yang terlarut didalamnya, diantaranya adalah vitamin B1, vitamin B3, vitamin B6, mangan $(\mathrm{Mn})$, fosfor $(\mathrm{P})$, zat besi (Fe) dan serat (Rahmadsyah, 2015). Sedangkan menurut hasil penelitian Wulandari et.al

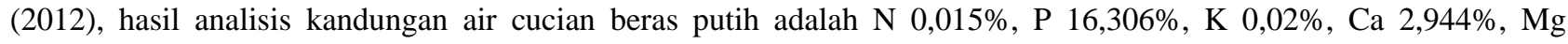
$14,252 \%$, S $0,027 \%$, Fe 0,0427\% dan B1 0,043\%.

Manfaat air leri ini juga telah diteliti oleh Andrianto (2007) yang menyatakan bahwa leri dapat merangsang pertumbuhan akar tanaman Adenium. Hal tersebut disebabkan karena leri mengandung vitamin B1 yang berfungsi merangsang pertumbuhan serta metabolisme akar. Pada penelitian ini pupuk organik dari leri disebut pupuk organik cair (POC) leri dan juga dilakukan fermentasi terhadap leri tersebut. Rasmito (2019) melaporkan bahwa pupuk organik cair dapat dibuat dari bahan organik cair (limbah organik cair), dengan cara fermentasi dan memberi aktivator sehingga dapat dihasilkan pupuk organik cair yang stabil dan mengandung unsur hara lengkap. Aktivator yang digunakan pada pembuatan pupuk POC leri adalah EM4. Aktivator ini sangat cocok dalam pembuatan pupuk organik cair karena dapat melakukan fermentasi secara anaerob pada bahan pupuk cair. Tujuan penelitian ini adalah untuk mengetahui komposisi POC leri yang terbaik dalam meningkatkan pertumbuhan dan produksi selada, serta untuk mengetahui pengaruh kombinasi media tanam dan POC leri terhadap peningkatan pertumbuhan dan produksi tanaman selada.

\section{BAHAN DAN METODE}

\section{Bahan dan Alat}

Bahan POC yang digunakan dalam penelitian ini adalah limbah air cucian beras atau leri, aktivator yang digunakan adalah EM4 dan gula merah. Tanah yang digunakan adalah ordo Ultisol yang terdapat di Desa Kari, Kecamata Kuantan Tengah, Kabupaten Kuantan Singingi. Untuk mengurangi kemasaman tanah diberi tambahan kapur giling dolomitik 100\% lolos saringan 20 mesh. Benih selada yang digunakan adalah varietas New Grandrapids. Bahanbahan lain yang digunakan adalah biochar arang kayu dan polybag berukuran $10 \mathrm{~kg}$.

Peralatan yang digunakan dalam penelitian ini adalah cangkul, parang, pisau, meteran, label, buku tulis, pena dan camera.

\section{Rancangan Penelitian}

Penelitian menggunakan metode rancangan acak kelompok (RAK) faktorial. Faktor pertama adalah pemberian biochar pada media tanam (M), yang terdiri dari: M1: Ultisol tanpa biochar dan M2: Ultisol + biochar. Faktor kedua adalah pemberian POC leri, dengan 5 perlakuan yang terdiri dari P0: tanpa pemberian POC leri, P1: pemberian POC leri tanpa fermentasi 1 kali seminggu, P2: pemberian POC leri tanpa fermentasi 2 kali seminggu, P3: pemberian POC leri dengan fermentasi 1 kali seminggu, dan P4: pemberian POC leri dengan fermentasi 2 kali seminggu.

Hasil penelitian ini diuji secara statistik dengan analisis ragam, dengan uji $\mathrm{F}$, dan bila terdapat perbedaan nyata dilanjutkan dengan uji Beda Nyata Jujur (BNJ) pada taraf 0,05.

\section{Pelaksanaan Penelitian}

Tanaman selada ditanam di dalam polybag yang diisi tanah Ultisol seberat $4 \mathrm{~kg}$, dan diberikan perlakuan pada media tanam (M), yaitu tanpa penambahan biochar (M1) atau dengan penambahan $30 \mathrm{~g}$ biochar (M2), serta diaduk rata. Selanjutnya dilakukan pemberian POC leri $(\mathrm{P})$ sesuai perlakuan. POC leri fermentasi dibuat di dalam ember $20 \mathrm{~L}$ 
yang memiliki penutup. Pembuatan POC leri disesuaikan dengan perlakuan pada penelitian ini dengan cara pembuatan sebagai berikut. Untuk perlakuan POC leri tanpa fermentasi dipersiapkan setiap saat akan melakukan pemberian perlakuan dengan cara menampung cairan cucian beras pertama dan dimasukan ke dalam ember $20 \mathrm{~L}$. Untuk perlakuan POC leri dengan fermentasi, $20 \mathrm{~L}$ air leri dimasukkan ke dalam ember $20 \mathrm{~L}$, lalu ditambahkan EM4 sebanyak $20 \mathrm{~mL}$ yang telah dilarutan dalam larutan gula. Selanjutnya ember ditutup dan diberi selang yang dihubungkan ke botol yang telah berisi air, dengan tujuan agar tidak terjadi ledakan karena gas yang dikeluarkan saat fermentasi. Proses fermentasi dilakuakn selama 14 hari. POC leri yang matang ditandai dengan warna lebih gelap, suhu kompos sama dengan suhu kamar atau tidak panas lagi. POC diberikan ke tanaman sebanyak $250 \mathrm{~mL}$ dengan konsentrasi 25\%, dengan interval pemberian sesuai perlakuan.

\section{HASIL DAN PEMBAHASAN}

\section{Tinggi Tanaman}

Hasil pengamatan tinggi tanaman $(\mathrm{cm})$ selada pada umur 35 hari setelah tanam (HST) setelah dianalisis ragam menunjukkan bahwa secara tunggal pengaruh pemberian biochar pada media tanam dan pemberian POC leri memberikan pengaruh yang nyata, tetapi interaksinya tidak memberikan pengaruh nyata terhadap tinggi tanaman selada. Rata-rata tinggi tanaman selada 35 HST dengan perlakuan media tanam dan POC leri disajikan pada Tabel 1.

Tabel 1. Rata-rata tinggi tanaman selada umur 35 HST dengan perlakuan media tanam dan POC leri (cm)

\begin{tabular}{lcccccc}
\hline Perlakuan & \multirow{2}{*}{$\mathrm{P} 0$} & $\mathrm{P} 1$ & $\mathrm{P} 2$ & $\mathrm{P} 3$ & $\mathrm{P} 4$ & Rata-rata M \\
\hline M & 13,40 & 21,82 & 25,62 & 26,12 & 30,57 & $23,51 \mathrm{~b}$ \\
M1 & 18,08 & 25,48 & 26,46 & 29,02 & 29,98 & $25,80 \mathrm{a}$ \\
\hline Rata-rata P & $15,74 \mathrm{c}$ & $23,65 \mathrm{~b}$ & $26,04 \mathrm{ab}$ & $27,57 \mathrm{ab}$ & $30,27 \mathrm{a}$ & 24,65 \\
\hline KK $=11,47 \%$ & \multicolumn{2}{c}{ BNJ P. 4,93} & &
\end{tabular}

Keterangan: Angka-angka pada kolom dan baris yang diikuti oleh huruf kecil yang sama adalah tidak berbeda nyata menurut uji lanjut BNJ pada taraf 0,05 .

Berdasarkan Tabel 1, secara tunggal pemberian perlakuan biochar pada media tanam tanah Ultisol pada perlakuan M2 merupakan perlakuan terbaik dengan tinggi tanaman selada 25,80 cm. Hasil uji lanjut beda nyata jujur (BNJ) pada taraf 0,05 menunjukkan bahwa perlakuan M2 berbeda nyata dengan perlakuan M1 (tanah ultisol murni). Jika dibandingkan dengan deskripsi tinggi tanaman selada new Grand Rapid pada Lampiran Keputusan Menteri Pertanian No. 198/kpts/sr.120/3/2006, deskripsi selada varietas New Grand Rapid memiliki tinggi tanaman 27-32 cm, maka tinggi tanaman pada perlakuan media tanam $(23,51-25,80 \mathrm{~cm})$ belum mencapai kriteria tinggi tanaman sesuai deskripsi. Hal ini disebabkan karena pada fase vegetatif, yaitu fase pertumbuhan tanaman lebih membutuhkan unsur hara $\mathrm{N}$, sedangkan biochar mengandung unsur hara $\mathrm{N}$ yang rendah karena adanya proses pembakaran pada pembuatan biochar, sehingga $\mathrm{N}$ menguap. Sifat $\mathrm{N}$ yang mudah menguap dan hilang karena panas dinyatakan oleh Hardjowigeno (2010).

Penggunaan biochar yang bersifat kaya karbon lebih memperbaiki struktur tanah dan perkembangan perakaran, sehingga secara angka terdapat perbedaan tinggi antara perlakuan M2 yang diberi biochar dengan media tanah Ultisol, yaitu dengan selisih 2,29 cm. Pengaruh biochar ini bersifat slow release sehingga belum terlihat jelas pada tanaman berumur pendek seperti selada. Hal ini mungkin disebabkan karena biochar secara umum mempunyai fungsi lebih persisten dalam tanah, sehingga semua manfaat yang berhubungan dengan retensi hara dan kesuburan tanah dapat berjalan lebih lama dibandingkan bahan organik lain. Aplikasi biochar secara nyata berpotensi dalam meningkatkan beberapa sifat kimia tanah, seperti pH tanah, KTK, dan kandungan beberapa senyawa seperti C-organik, N-total, serta peranannya mereduksi aktivitas senyawa Fe dan Al, yang akhirnya berdampak terhadap peningkatan P-tersedia. Biochar mengandung $\mathrm{C}$ organik yang masih tetap bertahan di dalam karbon hitam dan mempunyai pengaruh jangka panjang dalam mengkhelat unsur logam (Ferizal dan Basr, 2011; Zhang et al., 2013). Hal ini sesuai dengan penelitian Rondon et al., (2007) yang menyatakan bahwa penggunaan biochar dapat meningkatkan fiksasi nitrogen, memperbaiki pertumbuhan dan meningkatkan hasil tanaman. Novak et al., (2009) menyatakan pula bahwa penggunaan biochar dalam tanah masam di Amerika Serikat bisa meningkatkan $\mathrm{pH}, \mathrm{C}-$ Organik tanah, $\mathrm{Mn}$, dan Ca serta mengurangi $\mathrm{S}$ dan Zn dalam tanah berpasir

Pada Tabel 1 juga terlihat bahwa perlakuan P4 ( POC leri dengan fermentasi 2 kali seminggu) memberikan tinggi tanaman tertinggi, yaitu 30,27 cm Nilai ini berdasarkan uji BNJ pada taraf 0,05 tidak berbeda nyata dengan dengan perlakuan P3dan P4, tetapi berbeda nyata dengan perlakuan P1 dan P0. Perlakuan P4 dan P3 memberikan tinggi tanaman yang sudah sesuai deskripsi selada New Grand Rapid, sedangkan perlakuan lain belum. Hal ini disebabkan karena POC leri yang digunakan pada perlakuan tersebut telah difermentasi. Menurut Rasmito et al (2019) proses fermentasi pada bahan organik cair dapat meningkatkan kandungan hara POC. 
Perlakuan P2 dan P3 memberikan hasil tinggi tanaman yang tidak sesuai deskripsi karena POC yang diberikan hanya merupakan air cucian beras atau belum difermentasi sehingga unsur haranya masih rendah dibandingan POC leri yang telah difermentasi. Menurut hasil penelitian Wulandari et.al (2012), hasil analisis kandungan air cucian beras putih

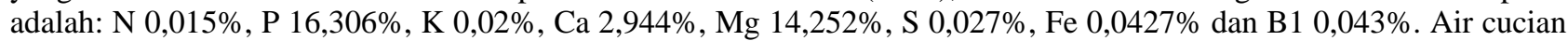
beras putih memiliki kandungan unsur hara $\mathrm{N}, \mathrm{P}, \mathrm{Mg}$, dan $\mathrm{S}$ yang lebih tinggi dibanding air cucian beras merah. Sedangkan jika air cucian beras difermentasi maka kandungan $\mathrm{N}$ nya meningkat menjadi $0,15 \% \mathrm{~N}$ untuk pupuk cair dari air cucian beras; hal ini memungkinkan karena ada penambahan molase sebanyak 7,5\% dan EM4 $50 \mathrm{~mL}$. Selanjutnya menurut Hanafiah (2005 N sangat berpengaruh terhadap pertumbuhan fase vegetatif, yang dicirikan oleh penambahan volume sel tanaman (tinggi dan panjang tanaman) dan organ tanaman lainnya, berupa daun dan cabang baru. Saat fase tersebut, peran unsur N sangat penting, khususnya pada saat pembelahan sel yang termasuk bagian dari proses metabolisme bagi tanaman.

Respon tanaman terhadap $\mathrm{N}$ sangat tergantung dari keadaan tanah, macam tanaman dan tempat tumbuh. Tanaman selada merupakan tanaman yang peka terhadap unsur N. Pemberian pupuk dalam konsentrasi yang sesuai dapat memberikan hasil yang tinggi. Perlakuan P0 (kontrol) memberikan tinggi tanaman yang paling rendah dibandingkan dengan perlakuan lainnya, dikarenakan kontrol digunakan sebagai perbandingan pada penelitian ini dan tidak diberi perlakuan apapun, sehingga tanah pada perlakuan kontrol kekurangan unsur hara. Ultisol menurut Hakim (2006) merupakan tanah yang rendah bahan organik dan miskin unsur hara N, sehingga tanaman yang ditanam pada tanah tersebut jika tidak dikapur akan tumbuh kerdil. Perbandingan pertumbuhan tanaman pada dua media dan pemberian POC leri yang berbeda-beda terhadap pertumbuhan tanaman selada dapat dilihat pada Gambar 1.

Dari Gambar 1 dapat dilihat bahwa pertumbuhan tanaman pada Gambar 1A menggunakan media tanah Ultisol lebih rendah dibandingkan tinggi tanaman pada Gambar 1B yang media tanahnya diberi biochar. Selanjutnya jika dibandingkan antar perlakuan pemberian POC leri pada masing masing Gambar 1A dan 1B, dimana pada Gambar 1A dari kanan ke kiri, sedangan pada Gambar 1B dari kiri ke kanan terlihat bahwa dengan pemberian POC leri fermentasi menghasilkan pertumbuhan tanaman lebih baik dibandingkan pemberian POC leri tanpa fermentasi. Dari gambar tersebut juga dapat dijelaskan bahwa perlakuan M2 secara umum lebih bagus pertumbuhan tanamannya, yang membuktikan bahwa biochar mempengaruhi secara positif pertumbuhan tanaman selada. Selanjutnya pemberian POC leri pada perlakuan P3 dan P4 adalah yang paling bagus; ini membuktikan bahwa POC leri yang telah difermentasi merupakan pupuk organik yang paling sesuai untuk pertumbuhan tanaman selada. Hal ini disebabkan karena dengan fermentasi bahan organik maka ketersediaan dan penyerapan unsur $\mathrm{N}$ dan $\mathrm{P}$ mampu meningkatkan pertumbuhan vegetatif tanaman.

\section{Jumlah Daun}

Hasil pengamatan jumlah daun tanaman selada (helai) pada 35 HST, setelah dianalisis ragam menunjukkan bahwa secara tunggal pengaruh pemberian biochar pada media tanam dan pemberian POC leri memberikan pengaruh yang nyata terhadap jumlah helai daun, dan tetapi interaksinya tidak memberikan pengaruh nyata terhadap jumlah helai daun tanaman selada. Rata-rata jumlah daun selada umur 35 HST dengan perlakuan media tanam dan POC leri dapat dilihat pada Tabel 2.

Berdasarkan Tabel 2, pemberian perlakuan secara tungga biochar pada media tanah Ultisol memberikan jumlah daun paling banyak pada perlakuan M2 (30 g biochar per polybag), yaitu 12,83 helai, dan jumlah daun yang paling sedikit terdapat pada perlakuan M1 (kontrol, tanpa biochar), yaitu 11,31 helai. Jika dilihat dari deskripsi tanaman selada secara umum jumlah daun adalah 5-16 helai per tanaman, berarti jumlah daun tanaman selada pada perlakuan media tanam telah mencapai potensi sesuai deskripsi.

Perlakuan M2 memberikan jumlah daun tertinggi; hal ini disebabkan karena pada pengamatan tinggi tanaman (Tabel 1) juga terlihat bahwa perlakuan M2 memberikan tinggi tanaman lebih tinggi daripada perlakuan M1 sehingga pertumbuhan tanaman lebih baik dan daun lebih berkembang.

Ketersediaan unsur hara yang terkandung dalam media tanam yang diberi biochar berada dalam keadaan cukup tersedia. Semakin tersedianya unsur hara yang dibutuhkan tanaman maka akan semakin banyak yang dimanfaatkan oleh tanaman untuk pertumbuhannya. Akibatnya, akan terjadi peningkatan proses metabolisme, utamanya peningkatan fotosintesis karena adanya ketersediaan N yang cukup tinggi. Proses ini akan menghasilkan karbohidrat yang lebih banyak, sehingga mempercepat pertumbuhan tanaman dan dapat meningkatkan jumlah daun pada tanaman selada. Hardjowigeno (2010) menyatakan bahwa pertumbuhan suatu taaman dipengaruhi oleh unsur hara, air, intensitas cahaya matahari, dan suhu udara.

Pada Tabel 2 juga terlihat bahwa secara tunggal pemberian POC leri mempengaruhi jumlah daun, dengan jumlah daun terbanyak terdapat pada perlakuan P4, yaitu 14, 42 helai. Nilai tersebut tidak berbeda nyata dengan perlakaun P3 dan P2, tetapi berbeda nyata dengan perlakuan P1 dan P0.

Unsur hara yang terkandung pada perlakuan P4 yang diberikan pada media tanam, terutama N, diserap akar dan diangkut ke tubuh tanaman, dibantu oleh air yang tersedia. Pembelahan dan pembesaran sel yang cepat karena adanya unsur $\mathrm{N}$ mengakibatkan daun muda lebih cepat mencapai bentuk sempurna, sehingga dapat meningkatkan jumlah daun tanaman selada. 


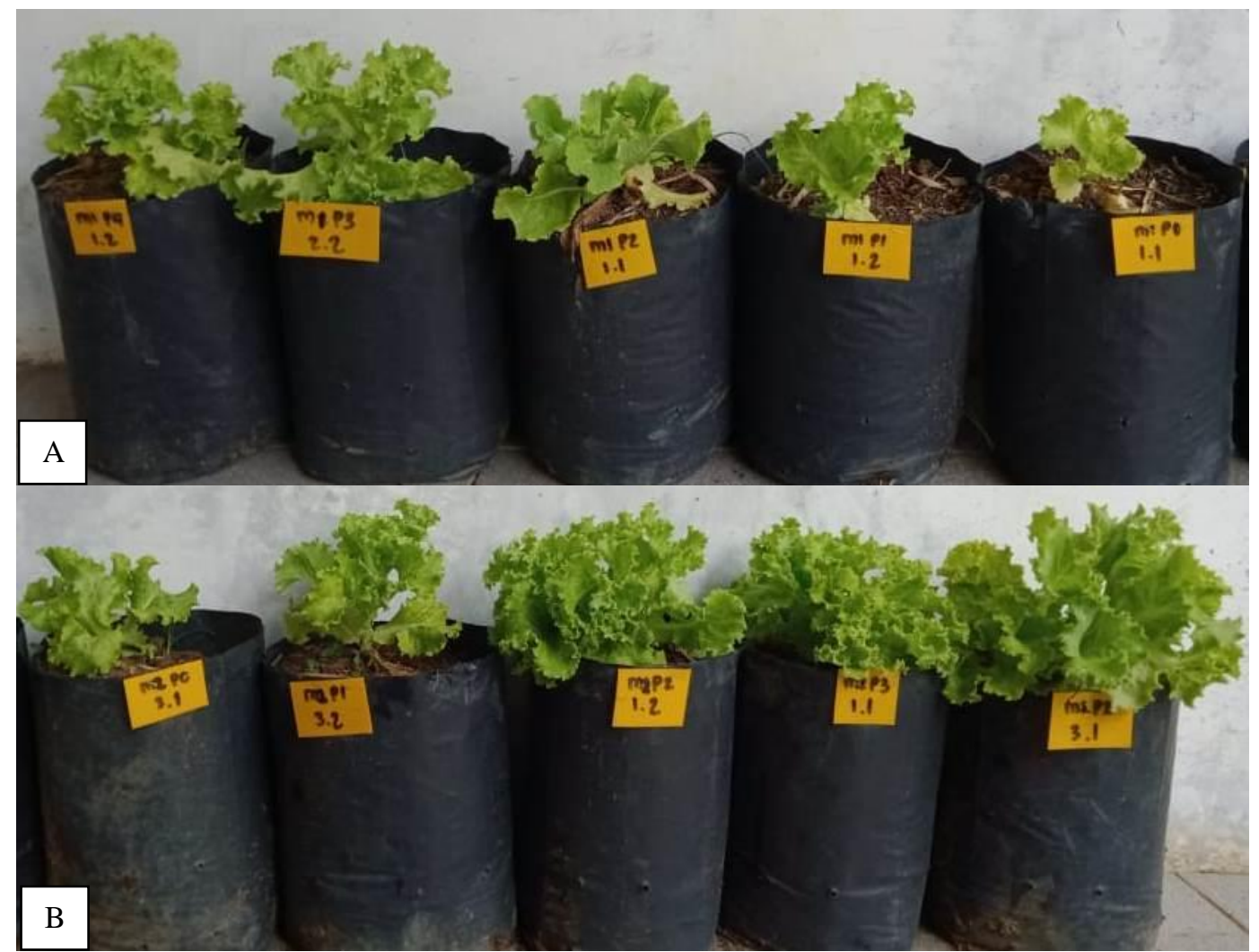

Gambar 1. Tanaman selada pada polybag dengan tanah Ultisol, dengan dan tanpa perlakuan biochar dan pemberian POC leri: A) pengaruh penggunaan media M1 dengan berbagai perlakuan POC leri P0, P1, P2, P3 dan P4 (dari kiri ke kanan); B) pengaruh penggunaan media M2 dengan berbagai perlakuan POC leri P0, P1, P2, P3 dan P4 (dari kanan ke kiri)

Tabel 2. Rata-rata jumlah daun tanaman selada umur 35 HST dengan perlakuan media tanam dan POC leri (helai)

\begin{tabular}{|c|c|c|c|c|c|c|}
\hline $\begin{array}{l}\text { Perlakuan } \\
\mathrm{M}\end{array}$ & $\mathrm{P} 0$ & $\mathrm{P} 1$ & $\mathrm{P} 2$ & P3 & $\mathrm{P} 4$ & $\begin{array}{c}\text { Rata-rata } \\
\text { M }\end{array}$ \\
\hline M1 & 7,49 & 9,50 & 12,31 & 13,35 & 13,90 & $11,31 b$ \\
\hline M2 & 12,74 & 10,43 & 12,49 & 13,56 & 14,93 & $12,83 \mathrm{a}$ \\
\hline Rata-rata P & $10,12 b$ & $9,97 b$ & $12,40 \mathrm{a}$ & $13,45 \mathrm{a}$ & $14,42 \mathrm{a}$ & 12,07 \\
\hline KK : 14,49 & $\mathrm{BN}$ & & $\mathrm{BNJ}$ & & & \\
\hline
\end{tabular}

Keterangan: Angka-angka pada kolom dan baris yang diikuti oleh huruf kecil yang sama adalah tidak berbeda nyata menurut uji lanjut BNJ pada taraf 0,05

Jumlah daun yang relatif rendah terdapat pada perlakuan P0 dan P1; hal ini juga sejalan dengan tinggi tanaman yang juga rendah (Tabel 1), dan juga dikarenakan pemberian POC leri dosis rendah pada P1 atau tidak ada pemberian POC leri pada perlakuan P0; akibatnya kondisi ini tidak mampu menyediakan atau mencukupi unsur hara yang dibutuhkan tanaman untuk pertumbuhan dan perkembangannya, baik unsur hara makro maupun unsur hara mikro.

Perlakuan P2 dan P3 cenderung tidak berbeda nyata dengan perlakuan P4 pada pengamatan jumlah daun; hal ini disebabkan oleh pemberian POC pada P2 lebih banyak frekkuensi, yaitu 2 kali seminggu, sedangkan pada P3 POC leri yang diberikan sudah dalam bentuk fermentasi meski diberikan 1 kali seminggu. Hal ini berarti pemberian dua kali seminggu POC leri tanpa fermentasi setara pengaruhnya terhadap jumlah daun dengan pemberian satu kali seminggu POC leri fermentasi.

\section{Berat Basah Tanaman (g/tanaman)}

Hasil pengamatan berat basah tanaman selada pada 35 HST (g per tanaman), setelah dianalisis ragam menunjukkan bahwa secara tunggal pengaruh tunggal pemberian biochar pada media tanam dan pemberian POC leri maupun interaksi memberikan pengaruh yang nyata terhadap berat basah tanaman. Rata-rata berat basah pada 35 HST dengan perlakuan media tanam dan POC leri dapat dilihat pada Tabel 3. 
Tabel 3. Rata-rata berat basah tanaman selada umur 35 HST dengan perlakuan media tanam dan POC leri (g per tanaman)

\begin{tabular}{lcccccc}
\hline Perlakuan & \multirow{2}{*}{ P0 } & P1 & P2 & P3 & P4 & Rata-rata M \\
\cline { 1 - 7 } M & $21,39 \mathrm{e}$ & $78,99 \mathrm{~d}$ & $95,90 \mathrm{~cd}$ & $136,39 \mathrm{abc}$ & $172,48 \mathrm{ab}$ & $101,03 \mathrm{~b}$ \\
M1 & $94,72 \mathrm{~cd}$ & $106,27 \mathrm{~cd}$ & $127,54 \mathrm{bcd}$ & $128,87 \mathrm{bcd}$ & $185,99 \mathrm{a}$ & $128,68 \mathrm{a}$ \\
\hline Rata-rata P & $58,05 \mathrm{~d}$ & $92,63 \mathrm{c}$ & $111,72 \mathrm{bc}$ & $132,63 \mathrm{~b}$ & $179,24 \mathrm{a}$ & 114,85 \\
\hline KK $: 16,02 \%$ & BNJ M: 14,19 & & BNJ P: 32,13 & & BNJ M $\times \mathrm{P}: 53,88$ \\
\hline
\end{tabular}

Keterangan: Angka-angka pada kolom dan baris yang diikuti oleh huruf kecil yang sama adalah tidak berbeda nyata menurut uji lanjut BNJ pada taraf 0,05

Berdasarkan Tabel 3, secara tunggal pemberian biochar pada media tanam tanah Ultisol memberikan berat basah tanaman tertinggi terdapat pada perlakuan M2, yaitu 128,68 g per tanaman dan berdasarkan uji BNJ pada taraf 0,05 berbeda nyata dengan perlakuan M1 (101,03 g per tanaman). Perlakuan M2 berbeda nyata dengan perlakuan M1 (27,65 g per tanaman). Jika dikaitkan dengan pengamatan tinggi tanaman maupun jumlah daun, dimana perlakuan M2 dengan dosis $30 \mathrm{~g}$ biochar per polybag menunjukkan hasil pengamatan dengan nilai terbaik; di sini terlihat bahwa semakin tinggi tanaman dan jumlah daun yang lebih banyak maka berat tanaman selada yang dihasilkan akan lebih tinggi pula.

Tabel 3 menunjukkan bahwa secara tunggal pemberian POC leri perlakuan P4 (POC leri fermentasi dan pemberian 2 kali seminggu) dengan berat basah 179,24 g per tanaman merupakan salah satu cara memenuhi kebutuhan hara tanaman yang optimal. Perlakuan P4 berbeda nyata dengan perlakuan P3, P2, P1 dan P0. Jika dikalkulasikan terdapat selisih antara perlakuan P4 dengan perlakuan P0, P1, P2 dan P3, secara berturut-turut nilainya adalah $121,19 \mathrm{~g}$ (P4-P0), 86,61 g (P4-P1), 64,52 g (P4-P2), dan 46,61 g (P4-P3). Perlakuan P4 dengan penggunaan POC leri yang telah difermentasi dan pemberian yang lebih sering, yaitu dua kali seminggu, menyumbangkan unsur hara N,P dan K yang lebih banyak, sehingga tanaman tumbuh lebih baik dan menghasilkan biomassa lebih banyak. Hasil tanaman akan dapat optimal apabila syaratnya terpenuhi, seperti tersedianya unsur hara yang cukup dan faktor lingkungan yang sesuai. Sesuai dengan Hanafiah (2005) yang menyatakan bahwa unsur hara sangat dibutuhkan untuk pertumbuhan tanaman, tanaman akan tumbuh dengan baik apabila unsur hara yang dibutuhkan cukup tersedia dan seimbang dalam bentuk yang sesuai untuk diserap tanaman. Apabila unsur hara makro dan mikro cukup tersedia maka pertumbuhan dan perkembangan tanaman akan lebih optimal. Unsur-unsur hara yang terkandung dalam POC leri, terutama N dan P, sangat berpengaruh dalam proses pembentukan dan pembelahan sel, sehingga memungkinkan pertumbuhan tanaman pada fase vegetatif sangat besar. Pembelahan sel terjadi pada pembuatan sel-sel baru; dan sel-sel ini memerlukan karbohidrat dari hasil proses fotosintesis dalam jumlah yang besar.

Berdasarkan Tabel 3, terlihat bahwa terdapat interaksi antara media tanam (M) dengan pemberian POC leri $(\mathrm{P})$ terhadap berat basah tanaman selada. Perlakuan terendah terdapat pada perlakuan M1P0 yang menggunakan media tanam Ultisol saja tanpa pemberian biochar maupun POC leri yang memperlihatkan tanaman tumbuh kerdil dengan tinggi paling rendah, yaitu 21,39 g per tanaman, dan berbeda nyata dengan perlakuan lainnya. Perlakuan tertinggi dalam menghasilkan berat basah selada adalah pada perlakuan M2P4 (185,99 g per tanaman), dengan media tanam Ultisol ditambah $30 \mathrm{~g}$ biochar per polybag dan diberi POC leri fermentasi sebanyak dua kali seminggu. Berarti ada selisih yang sangat jauh (164,60 g per tanaman) terhadap perlakuan kontrol M1P0. Perlakuan kontrol menghasilkan bobot segar yang paling rendah; hal ini karena pada perlakuan tersebut tanaman kekurangan unsur hara.

Dari hasil analisis berat segar per tanaman, ternyata produksi yang tinggi terdapat pada perlakuan M2P4, yaitu 185,99 g per tanaman. Jika dibandingkan dengan deskripsi berat bersih tanaman selada varietas New Grand Rapid, yaitu 570-635 g per tanaman, maka berat tanaman pada penelitian ini belum mencapai hasil sesuai deskripsinya. Hal tersebut disebabkan karena pada penelitian ini tidak menggunakan pupuk anorganik sama sekali.

\section{KESIMPULAN}

Berdasarkan penelitian yang telah dilakukan dapat disimpulkan sebagai berikut:

1. Komposisi POC leri yang terbaik dalam meningkatkan pertumbuhan dan produksi selada adalah $25 \%$ POC leri fermentasi dengan pemberian 2 kali seminggu, yang diberikan sebanyak $250 \mathrm{~mL}$ per tanaman selada.

2. Berdasarkan perlakuan secara tunggal, media tanam terbaik adalah $\mathrm{M} 2$ (tanah Ultisol $+30 \mathrm{~g}$ biochar per polybag dengan $4 \mathrm{~kg}$ media tanah), dengan tinggi tanaman 25,80 cm, jumlah daun 12, 83 helai; dan perlakuan POC leri terbaik terdapat pada perlakuan P4 (POC leri fermentasi yang diberikan dua kali seminggu), yaitu dengan tinggi tanaman 30,27 cm dan jumlah daun 14,42 helai. Sedangkan untuk berat basah tanaman selada tertinggi terdapat pada perlakuan M2P4 (media tanam + biochar dan POC leri fermentasi yang diberikan dua kali seminggu), yaitu 185,99 g per tanaman. 


\section{UCAPAN TERIMA KASIH}

Terima kasih diucapkan kepada ketua LPPM dan Rektor Universitas Islam Kuantan Singingi, yang telah memberikan hibah dana penelitian untuk terlaksananya penelitian ini.

\section{DAFTAR PUSTAKA}

Andrianto, H. 2007. Pengaruh Air Cucian Beras pada Adenium. Skripsi. Fakultas Keguruan dan Ilmu Pendidikan, Universitas Muhamadiyah Surakarta, Surakarta.

Dinas Tanaman Pangan Kabupaten Kuantan Singingi. 2013. Laporan Tahunan Dinas Tanaman Pangan Kabupaten Kuantan Singingi, Teluk Kuantan.

Ferizal, M. dan A.B. Basr. 2011. Arang Hayati (Biochar) Sebagai Pembenah Tanah. Balai Pengkajian Teknologi Pertanian (BPTP) Aceh, Lampineung, Banda Aceh.

Hakim, N. 2006. Pengelolaan Kesuburan Tanah Masam dengan Teknologi Pengapuran Terpadu. Andalas University Press, Padang.

Hanafiah, K.A. 2005. Dasar-Dasar Ilmu Tanah. Rajagrafindo Persada. Jakarta. ISBN: 979-3654-30-9.

Hardjowigeno. S. 2010. Ilmu Tanah. Akademi Pressindo. Jakarta. ISBN: 9789798035562.

Harryadi, A. 2016. Pengaruh Residu Biochar terhadap Pertumbuhan dan Serapan N dan K Tanaman Kedelai (Glycine max L.) pada Topsoil dan Subsoil Tanah Ultisol. Skripsi. Program Studi Agroteknologi. Fakultas Pertanian, Universitas Lampung. Lampung.

Haryanto, E. 2003. Sawi dan Selada. Penebar Swadaya, Jakarta.

Novak, J.M., I.M. Lima, B. Xing, J.W. Gaskin, C. Steiner, K.C. Das, M. Ahmedna, D. Rehrah, D.W. Watts, W.J. Busscher, and H. Schomberg. 2009. Characterization of designer biochar produced at different temperatures and their effects on a loamy sand. Annals of Environmental Science 3: 195-206. ISSN 1939-2621. www.aes.northeastern.edu.

Rahmadsyah. 2015. Pengaruh Air Leri, Air Teh Basi dan Air Kopi Sebagai Larutan Nutrisi Alternatif Terhadap Budidaya Bayam Merah Dengan Metode Nutrien Film Technique. Skripsi. Program Studi Biologi, Universitas Islam Negeri Sunan Kalijaga, Yogyakarta.

Rasmito, A., A. Hutomo, dan A.P. Hartono. 2019. Pembuatan pupuk organik cair dengan cara fermentasi limbah cair tahu, starter filtrate kulit pisang dan kubis, dan bioaktivator EM4. Jurnal Iptek 23(1): 55-62. DOI: 10.31284/j.iptek.2019.v23i1.496.

Rondon, M., J. Lehmann, J. Ramirez, and M.Hurtado. 2007. Biological nitrogen fixation by common beans (Phaseolus vulgaris L.) increases with bio-char additions. Biology and Fertility of Soils 43:699-708. https://link.springer.com/article/10.1007/s00374006-0152-z.

Wulandari, C., S. Muhartini, dan S. Trisnowati. 2012. Pengaruh air cucian beras merah dan beras putih terhadap pertumbuhan dan hasil selada (Lactuca sativa L.). Vegetalika 1(2). DOI: https://doi.org/10.22146/veg.1516.

Zhang, X., H. Wang, L. He, K. Lu, A. Sarmah, J. Li, N.S. Bolan, J. Pei, and H. Huang. 2013. Using biochar for remediation of soils contaminated with heavy metals and organic pollutants. Environmental Science and Pollution Research International 20(12): 8472-8483. DOI: $10.1007 / \mathrm{s} 11356-013-1659-0$. 